\title{
ADAPTIVE SPORTS: FEATURES OF ITS ORIGIN AND PROBLEMS OF DEVELOPMENT
}

\section{Irina Kohut, Tatyana Kropionitskaya, Ievgen Goncharenko, Viktorya Marynych, Sergey Matvieiev}

\begin{abstract}
Анотація. У роботі визначено групи передумов виникнення та розвитку адаптивного спорту. Перша група пов'язана з накопиченням знань про позитивний вплив спорту на організм людей. Друга - обумовлена процесами демократичних перетворень у сучасному суспільстві. Третя група визначає зростання популярності гуманістиних цінностей у світі. Розглянуто специфічні риси розвитку паралімпійського і дефлімпійського спорту в Україні, що обумовлюють позитивну динаміку виступів вітчизняних спортсменів на міжнародній арені. Дано характеристику проблем адаптивного спорту, основними з яких є: 1) організаційні, структурні та функціональні проблеми; 2) проблеми рівня чесності суспільства; 3) морально-етичні проблеми. Виявлено проблеми використання допінгу під час Паралімпійських ігор. Проаналізовано в історичному аспекті антидопінгову діяльність під час проведення Паралімпійських ігор у період з 1992 р. (Барселона) до 2016 р. (Ріо-де-Жанейро). Встановлено тенденцію до збільшення допінг-проб на Паралімпійських іграх, що відповідає ситуації в олімпійському спорті. Якщо у 1992 р. загальна кількість допінг-проб становила 300, то в Ріо-де-Жанейро їх було більше ніж у п'ять разів - 1681. Виявлено, що проблема допінгу характерна і паралімпійському спорту, що обумовлено поступовим переходом від реабілітаційної спрямованості адаптивного спорту до спорту вищих досягнень. Проведено порівняльну характеристику антидопінгових кампаній на Олімпійських і Паралімпійських іграх.

Детальний аналіз зазначеної проблеми дозволив встановити, що у паралімпійському спорті характерною $є$ обмежена кількість видів спорту порівняно з олімпійським, де спортсмени свідомо порушили антидопінгові правила. Виявлено, що боротьба з допінгом у паралімпійському спорті більш диференційована та вимагає подальшого вдосконалення і врегулювання у зв'язку із необхідністю використання спортсменами препаратів з терапевтичною метою.
\end{abstract}

Ключові слова: адаптивний спорт, паралімпійський спорт, допінг, Паралімпійські ігри.

\begin{abstract}
The groups of conditions for the origin and the development of adaptive sports are defined in the work. The first group is associated with the accumulation of knowledge about the positive impact of sport on the human body. The second group is due to the processes of democratic transformations in modern society. The third group is determined by the growing popularity of humanist values in the world. The specific features of the development of the Paralympic and the Deaflympic sports in Ukraine causing the positive dynamics of the performances of national athletes in the international arena are determined. The problems of adaptive sports are characterized. The main issues are: 1) organizational, structural and functional problems; 2) problems of the level of honesty of society; 3) moral and ethical problems.

Doping problems in the Paralympics are detected. In particular, the historical analysis of anti-doping activities during holding the Paralympic Games from 1992 in Barcelona to 2016 in Rio de Janeiro is presented. There is a tendency to increase doping tests in the Paralympic Games, which corresponds to the situation in the Olympic sport. In 1992, the total number of doping tests was 300, and in 2016, in Rio de Janeiro their number was more than five times larger - 1681. Currently, the doping problem is illustrative of the Paralympic sports, which is due to the gradual transition from the rehabilitation focus of adaptive sports to elite sport. The comparative description of anti-doping campaigns at the Olympic and the Paralympic Games is presented.

A detailed analysis of this problem has made it possible to define that the Paralympic sport is characterized by a limited number of sports events in comparison with the Olympic sport, where athletes have deliberately violated the anti-doping rules. It is found that the fight against doping in the Paralympic sports is more nuanced and requires further improvement and regulation, which is caused by the necessity of athletes to use medicinal products for therapeutic purposes.
\end{abstract}

Keywords: adaptive sports, Paralympic sport, doping, Paralympic Games.

Introduction. Development of adaptive sport as one of the greatest achievements of the twentieth century humanism, promotes the participation of people with disabilities in the international sports movement as well as healthy people. While doing sports and participating in competitions, people with disabilities implement their potential, temper their spirit and will, achieve success in various areas of modern life. [1]

One of the Adaptive Sports' branches is the Paralympic movement that is based on humanistic ideals that are inherented in Olympism. This movement gives a life to the rights of people with disabilities to act in sport without any discrimination. Their con- 
cepts are based on the mutual understanding, friendship, solidarity and fair play. The Paralympic Games are held under the patronage of the IOC in the same sport facilities and with the same squad of judges after a few weeks after the Olympic Games. [2]

However, as the practice shows, with a powerful positive impact of the Olympic traditions and the principles on the sport movement of people with disabilities, unfortunately come disadvantages of the modern Olympic sport too. This leads to problems that negatively affect the development of the Paralympic sports.

Objective - to reveal the background of adaptive sports' origin and to characterize the problem of doping in modern Paralympic sport.

Materials and methods. Analysis of specialized literature, Internet sources; system analysis; synthesis and generalization; analogy and systematization.

Results. At all times sport for people with disabilities was effectively used for rehabilitation and cultivation of the character. Analysis of specialized literature and practice allows to select three groups of prerequisites that justify the origin and further formation of adaptive sport as an institution, and socio-cultural phenomenon of our time:

- Group 1 of prerequisites is associated with the centennial accumulation of knowledge about the sport and its impact on the body of people, including people with disabilities;

- Group 2 is directly connected with the processes of democratization of modern public relations;

- Group 3 exists due to the increasing popularity of humanistic ideas, especially in the second half of the twentieth century, which contributed to the enhancement of the role and social importance of adaptive sports in modern society.

According to WHO research in 2011 - $15 \%$ of the total population of our planet have disabilities and unfortunately this number is constantly increasing [10]. Ten years ago the number of people with disabilities was $5 \%$ less. According to statistics, every fourth family faces the problem of disability. Every day the number of people with diasabilities increases on 23 thousand, therefore, every year it becomes 8 million more of them.

Today, there are about 1 billion persons with disabilities in the world. Just imagine, this number equals the population of such country as China. In Ukraine, the official status of people with disabilities have about 3 million of citizens (for real, their number is much bigger), representing $6 \%$ of the total population. $50 \%$ of them are people of $1^{\text {st }}$ and $2^{\text {nd }}$ group of disability, which means that they regularly face the challenge of ensuring their own existence, as their disability causes difficulties with finding a job. According to the State Statistics Committee of Ukraine only $38 \%$ of the people with disabilities in the age from 18 to 60 are employed. Therefore, it is obvious that society has an important responsibility in solving socio-economic problems of this category of people [6].

At the same time, in practice, especially in countries such as Japan, Australia and in most of developed European countries and the United States, the use of means of adaptive sport for socialization of persons with disabilities can promote achieving of significant positive results in this area, which confirms the exceptional value of sport as a socio-cultural phenomenon of our time, and, consequently, it also confirms its economic viability for any state including Ukraine.

Adaptive sports in our country, officially appeared a little more than a quarter of a century ago. During this time, the athletes of Ukraine reached phenomenal results: from the $44^{\text {th }}$ place at the Summer Paralympics 1996 to the $4^{\text {th }}$ place - in 2013. Deaflympic athletes have the same dynamics of performances: from the 12th place in the summer Deaflimpic games 1993 up to the 1st place in Deaflympics 2005

Ukraine is the only country in the world with:

- established state control system of adaptive sports - "Invasport";

- officially approved program of its support;

- established facilities for Paralympic and Deaflympic training and rehabilitation of persons with disabilities in the Southern region (Yevpatoriya) and in the Western region (Lviv region.);

- a range of President's Decrees and Resolutions of the Cabinet of Ministers on the development of sport for people with disabilities and their social protection.

However, as practice shows, adaptive direction of contemporary international and domestic sports movement also has some problems that limit the pace of its further development. The main ones are: 1) organizational, structural and functional problems; 2) problems of society's level of civility; 3) moral and ethical problems.

The presence of the first group of problems is caused by the lack of a single international center of management of various branches of adaptive sports. This complicates the coordination of financial processes, training and recruitment, transportation support, creating of living places for athletes and other sport facilities needed for holding the competition.

The second group of problems depends on the level of the general culture of the society and, in particular, on the degree of humane attitude of the population towards people with disabilities. The attitude of society to the citizens with disabilities defines its level of civility. This shows out in the care of the state: in social security of this category of people, creating the necessary conditions for them, cre- 
ating a "barrier-free" facilities (ramps, lifts, wheelchairs, vehicles, etc.).

Third group is associated with the violation of the principles of justice: the allocation of athletes in classification groups; the use of doping; misuse of stressful workout regimes; small number of people with disabilities involved in sport; using of the adaptive sport for achieving personal goals, etc.

This publication will more detailed focus on the third group of problems. As a matter of fact, the discrediting of Olympic principles by desire to win at any price has brought the Olympic sport serious moral issues. Today in Paralympic sport accents offset from adaptive direction of trainings to the direction of achieving high results, which often leads to unintended negative consequences and is a prerequisite to the emergence of the moral and ethical problems. The most acute problem among them is a use of illicit drugs by athletes.

There is much in common between the Olympic and Paralympic sports, including common methods of the fight against doping. The list of prohibited substances is the same for all athletes. In 2003 The International Paralympic Committee (IPC) joined the following of the World Anti-Doping Code, developed by the World Anti-Doping Agency (WADA). Since then, out-of-competion control was set. However, the problem remains unresolved.

Doping control at the Summer Paralympic Games has appeared in the United Kingdom (Stoke-Mandeville, 1984), when it was carried out a pilot test, and in 1988 in Seoul - the official procedure for determining the use of doping substances was held. No positive samples on those doping tests were identified.

For the first time in Paralympic sport the talk about the issue of use of the doping began in the
1992 Paralympic Games in Barcelona (Table. 1). Three athletes were accused of using banned drugs.

At the Games in Sydney in 2000, the number of such cases reached 11, 10 of them - in powerlifting. The head of the medical commission of the IPC Dr. Bjцrn Hedman admits that the first positive doping sample in the history of the Winter Paralympic Games is taken from the German skier Thomas Oelsnera. He was the participant of VIII Paralympic Winter Games in Salt Lake City (2002). A positive result was get after athlete's winning of the race in the biathlon. All Oelsnera's samples, taken before the Paralympics, were negative. A member of the IPC Miguel Sagarra told reporters: "I wish that this was the first and the last press conference on doping."

However, at the Paralympic Games in Athens 2004, ten cases of the use of prohibited substances was registered. Canadian sprinter Earle Connor, was considered to be one of the favorites for medals in the sprint but did not take part in the Games in 2004 because of problems with doping. Connor's precompetitive tests revealed the presence in his body the traces of banned substances - testosterone and nandrolone [4].

Athlete himself explained this unpleasant fact as a result of a number of health problems he had. "I just wanted to go to the Paralympics completely healthy", - said Canadian runner in his statement. 28-year-old Connor took full responsibility for the presence of drugs in his body. The athlete made it clear that illegal drugs were taken by him as a part of medication prescribed to him by doctors in connection with the recovery after the operation, as well as acute stomach infection.

Also for the use of anabolic steroids were disqualified two powerlifters from Azerbaijan Sarah Abbasova and Gunduz Ismayilov. For both athletes it was their second time in the exposure of doping so they were banned for life.

Traces of prohibited drug 'furosemide' were found in the body of 41-year-old Estonian powerlifter Alexander Korolev. Syrian and Iranian powerlifters Younes Yousef and Ali Hosseini were also caught on using of doping. In their samples anabolic drugs were found. All three athletes were dropped from the Games and suspended for two years.

In addition, the IPC decided to deprive the silver medal for the tandem cycling of the Slovak cyclist Yuri Petrovich. In his samples was found a banned substance 'methylprednisolone'. His partner Vladislav Yanovzhaka was not found guilty of using the doping but anyway 
was forced to return the silver medal of the Games as the results of Petrovich in racing a tandem bike can not be separated from the results of his partner.

During Paralympics in Athens 2004 Cuban judoka Sergio Arturo Perez was deprived of the gold medalfor using the doping. According to the statement of the IPC, in athlete's doping sample the traces of illicit prednisolone were found.

Before the start of the Paralympic Games in Beijing in 2008 three positive doping tests were revealed. All of them belonged to powerlifters: Naveed Ahmed Bout from Pakistan, Fakura Sissoko from Mali and Lyudmila Osmanova from Ukraine. For the use of steroids these athletes were banned from the Games and later sentenced to two-year suspension [5].

German basketball player Ahmet Coskun was also excluded from participation in the Paralympic Games. His doping test taken before the event, gave a positive result. Athlete said that illegal drug finasteride was a part of anti-baldness medicament, which he used. 33-year-old basketball player expressed his disappointment about that situation. According to the sportsman, he did not know that the remedy for hair loss may contain a prohibited substance.

At the Beijing Games doping control of horses was held for the first time.

The second case of a positive doping test at the Paralympic Winter Games was in Vancouver 2010. In the sample of a 54-year-old Glenn Ikonen from the Swedish curling team was found banned drug metoprolol. This substance is of the class of betablockers. The athlete admitted that he was taking a prescribed by a doctor medication to lower blood pressure for three years [6].

At the Paralympic Games in London 2012 there were also some doping - scandals. First of all, in samples of Russian powerlifters Vadim Rakitin and Nikolai Marfina was found a growth hormone. Then, Shota Omarishvili from Georgia was caught on the use of steroids [7].

In 2014, there was an unprecedented event in the history of Olympic and Paralympic sports. For the first time ever, WADA, the IOC and the IPC faced not with the problem of use of illegal drugs by individual athletes, but with the state doping program. As a result of the work of special commissions of the IOC and the IPC it was established that a significant number of samples of the representatives of the national team of the Russian Federation had had external damage which might indicate a replacement of the tests, or introduction of additional substances in the samples.

As a consequence, the entire Paralympic team of the Russian Federation was excluded from participation in the Paralympic games 2016 in Rio. This decision is quite questionable, because those were the representatives of winter sports who had competed in Sochi, and the IPC suspended summer sports athletes. However, this is how the President of the IPC, Philip Craven, commented on the decision: «The anti-doping system in Russia is broken, corrupted and completely compromised. I believe that the Russian government disastrously let down their Paralympic athletes. I find their approach «medals are more important than morals» disgusting» .

At the moment, the commissions of the IOC and the IPC continue the investigation of the precedent. This situation motivated the organizers of the Olympic and Paralympic games in 2016 to treat the issue of doping control in a very responsible manner. In particular, during the Paralympic games there were taken 1320 samples for testing participants: $777 \mathrm{di}-$ rectly during the competitions and 543 on the days out of competition.

Thus, the study of issues related to the testing of Paralympic athletes for the presence of prohibited substances in their bodies shows the relevance of this problem. Despite the rapid increasing of the number of doping tests taken, severe punishment of athletes implicated in the use of prohibited substances, the problem remains unresolved.

At the first glance comparative analysis of the ratio of the number of positive doping tests to the total number of samples taken at the Olympic and $\mathrm{Pa}-$ ralympic Games shows that the situation with doping in Paralympic sport is worse thanin Olympic. On the other hand, detailed examination of each individual case shows the limited number of sports (mainly weightlifting) were athletes consciously break anti-doping rules. Secondly, it shows that athletes often make unfortunate mistakes and even doctors can make a prescription of various drugs containing banned substances.

Today this list includes more than 10 thousand names that restricts the use of different drugs in treating people with functional abnormalities in health status (primary or secondary diseases). Training process of the athletes in Paralympic sports is not alaways performed along with a help of qualified in these matters medical accompaniment. The situation is also complicated with the insufficient number of consultations, technical clarifications on issues of allowed and prohibited substances, the results of doping tests and with the lack of cooperation on the exchange of pharmaceutical support technologies.

Conclusions. As the practice shows, the modern Olympic sport affects the Paralympic sport not only with its traditions and general principles. Excessive exercises and the desire to win at any cost, even in violation of the ethical principle became the realities of modern Paralympic sport. 
The doping problem in Paralympic sport is complex and controversial. The main contradictions are:

- the emergence of Paralympic sport as a recreational and rehabilitation field and the desire to achieve maximum results (sometimes at any cost) at the present stage;

- Declaration of ideas of Olympism and periodical breaking of them;

- taking of banned drugs by athletes with disabilities can improve the result, but also it can exacerbate the health and cause a secondary disease;

- existence of expensive anti-doping policies in Paralympic sport and lack of its effectiveness in some cases;

- constant expansion of the list of prohibited substances, the rapid increasing of the number of doping tests alongside regular detection of small amounts of drugs and mostly in samples of athletes of particular kinds of sport (weightlifting);

- equal kinds of punishment for either conscious or accidental violators of Anti-Doping Code;

- the possibility of therapeutic use of illicit drugs with the permission of the relevant authorities and the manipulation of trainers, doctors and athletes to legitimize their admission;

- increased need of Paralympic athletes (as compared to the Olympics) in the treatment of injuries and diseases alongside limitation of the possibilities of using effective drugs, related to doping;

- rigid system of controls and penalties for taking illicit drugs and the absence of consultations and technical explanations on it.

Conflict of interest. The authors state that there is no conflict of interest.

\section{References}

1. Honcharenko I. V. Moral and ethical aspects in adaptive sport / I. V. Honcharenko, I. O. Kohut // Pedahohika, psykholohiia ta medyko-biolohichni problem fizvykhovania i sportu: Collection of scientific papers. - 2007. N 11. - P. 28-30.

2. Doping has entered the Paralympic sport: [Electronic resource]. - Access mode: http://skirun.ru/2012/09/09/ paralympian-sports-doping.

3. Kohut I. O. Socio-humanistic bases of adaptive physical culture development in Ukraine: monograph I I. O. Kohut. - Lviv: SPOLOM, 2015. - 284 p.

4. Historical, organizational and social aspects of adaptive sport development: teaching guide for physical education and sport institutions / [S. F. Matveiev, I. A. Briskin, I. O. Kohut et al.] - Kyiv : Askonit, 2011. - 250 p.

5. Matveiev S. Actual problems of footballers' preparation for Special Olympiads / S. Matveiev, M. Iarmolenko, I. Honcharenko // Teoriya i metodyka fizvykhovannia i sportu. - 2015. - N 4. - P. 71-74.

6. One of favourites of the Olympiad took doping: [Electronic resource]. - Access mode: http://www.newsru. com/sport/16sep2004.

7. Paralympic Games: [Electronic resource]. - Access mode: http://www.thecanadianencyclopedia.com/ articles/paralympic-games.

8. Pereira H. M. G. Doping control analysis at the Rio 2016 Olympic and Paralympic Games / H. M. G. Pereira, V. F. Sardela, M. C. Padilha et al. // Drug testing and analysis, 2017. -9(11-12). - P. 1658.

9. Record Number of Doping Tests Conducted in Beijing : [Electronic resource]. - Access mode: http://www. paralympic.org/press-release/record-number-doping-tests-conducted-beijing.

10. Sobolevsky, Tim, et al. "Anti-doping analyses at the Sochi Olympic and Paralympic Games 2014." Drug testing and analysis 6.11-12 (2014): 1087-1101. 